This article was downloaded by: [130.132.123.28]

On: 04 J anuary 2015, At: 14:23

Publisher: Routledge

Informa Ltd Registered in England and Wales Registered Number: 1072954

Registered office: Mortimer House, 37-41 Mortimer Street, London W1T

3J H, UK

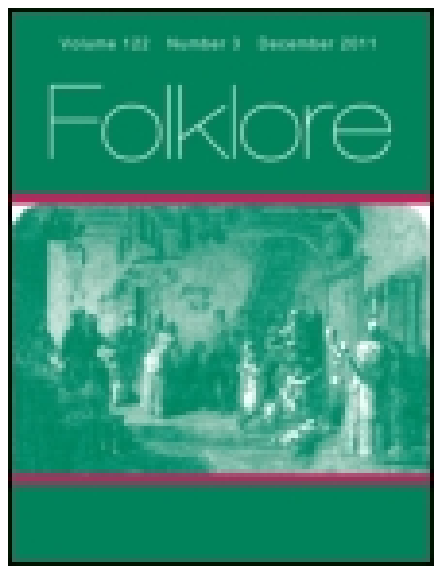

\title{
Folklore
}

Publication details, including instructions for authors and subscription information:

http:// www. tandfonline.com/loi/rfol20

\section{The Edinburgh Dinnshenchas}

Whitley Stokes

Published online: 14 Feb 2012.

To cite this article: Whitley Stokes (1893) The Edinburgh Dinnshenchas, Folklore, 4:4, 471-497, DOI: 10.1080/0015587X.1893.9720182

To link to this article: http:// dx. doi.org/ 10.1080/0015587X. 1893.9720182

\section{PLEASE SCROLL DOWN FOR ARTICLE}

Taylor \& Francis makes every effort to ensure the accuracy of all the information (the "Content") contained in the publications on our platform. However, Taylor \& Francis, our agents, and our licensors make no representations or warranties whatsoever as to the accuracy, completeness, or suitability for any purpose of the Content. Any opinions and views expressed in this publication are the opinions and views of the authors, and are not the views of or endorsed by Taylor \& Francis. The accuracy of the Content should not be relied upon and should be independently verified with primary sources of information. Taylor and Francis shall not be liable for any losses, actions, claims, proceedings, demands, costs, expenses, damages, and other liabilities whatsoever or howsoever caused arising directly or indirectly in connection with, in relation to or arising out of the use of the Content.

This article may be used for research, teaching, and private study purposes. Any substantial or systematic reproduction, redistribution, reselling, loan, sub-licensing, systematic supply, or distribution in any form to anyone is 
expressly forbidden. Terms $\&$ Conditions of access and use can be found at http://www.tandfonline.com/page/terms-and-conditions 


\title{
THE EDINBURGH DINNSHENCHAS.
}

\begin{abstract}
$A$ MONG the little-known Gaelic manuscripts preserved $A$ in the Advoçates' Library, Edinburgh, M. Henri Gaidoz discovered five leaves of a vellum copy of the Dinnshenchas, written (I should say) at the end of the fifteenth century, and now marked XVI Kilbride. For a loan of these leaves I am indebted to the kindness of the Curators and the Librarian, Mr. J. T. Clark. Like all the other copies of this curious collection of topographical legends, XVI Kilbride is imperfect; but, so far as it goes, it agrees closely, both in contents and arrangement, with the Oxford Dinnshenchas published in FolkLore, vol. iii, pp. 469-5 I5. The articles still remaining in the Edinburgh copy are as follows:
\end{abstract}

fo. Is. The Introduction, and part of Cuan O'Lochan's poem, Temair, Taillti, tir n-oenaig, etc., both now almost wholly illegible.

$I^{b}$ I. End of Cuan O'Lochan's poem - Teamhair Magh mBreagh.

Ib 2. Laighin, incomplete. Here a leaf is lost.

$2^{\mathrm{a}}$ I. Nine quatrains of Eochu Eolach's poem on Loch Garman, of which there is a complete copy in the Book of Leinster, p. 196-Fidh nGaible.

$2^{\text {a }}$ 2. Midhe-Ethne.

$2^{\mathrm{b}}$ I. Brí Léith-Tond Clidhna.

$2^{\text {b }}$. Slíabh Bladma.

$3^{\text {a }}$ I. Magh Roigne-Tebtha [leg. Tethba]-Loch nAinnind.

1 See the Revue Celtique, vi, I13. 
$3^{2}$ 2. Berbha-Magh Femhin-Sliabh Mis-Loch Léin.

$3^{\mathrm{b}}$ I. Sliabh Cua-Luimnech-Sliabh n-Echtga.

$3^{\text {b }}$ 2. Magh n-Aighni [leg. n-Aidhni]-Port Lairgi. Here, probably, three leaves are lost.

$4^{2}$ I. The final quatrain of the article Tuagh Inbhir; Bard Maile's poem about Tuagh Inbir, also in the Book of Leinster, pp. $152^{b}, 153^{a},-$ Beann Bogaine.

$4^{\text {a } 2 . ~ M a g h ~ C o r a i n d-L o c h ~ n-E c h a c h . ~}$

$4^{\text {b }}$ I. Loch n-Eirne-Sliabh Beatha.

4h 2. Coire mBrecan-Beann Foibhne-Ard Fothaidh -Ard Macha.

$5^{\text {a }}$ 1. Magh Coba-Sliabh Callainn-Sliabh Fuait.

$5^{\text {a }}$. Lia Lindgadain-Magh Mughna.

$5^{\text {b }}$ I. Findloch Cera-Magh Tailten-Beand Bairchi-Tráigh Tuirbhe-Lusmagh.

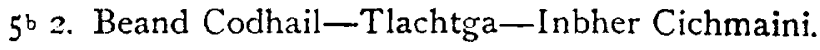

It will be seen that the Oxford Dinnshenchas does not contain the last twenty-two of these articles, and the primary object of this paper is to print the twenty-two faithfully, with literal translations and such notes as seem likely to elucidate what often, in spite of all my efforts, remains obscure. I have added, by way of supplement, three other articles found in Egerton $\mathrm{I} 7 \mathrm{SI}$, a vellum in the British Museum, and hitherto, so far as I know, unpublished. The articles now printed are numbered consecutively, in continuation of the fifty-two already published in this Journal. Those most likely to interest folklorists are Nos. 55, 61, 64, 67, 69, 70, 73. In the notes, "BB." means the Book of Ballymote; "H." the Dublin vellum H. 3. 3; "Lec." the Book of Lecan; "LL." the Book of Leinster; and "R." the Irish MS. at Rennes. 


\section{The Edinizurgh Dinnshenchas.}

(Kilbride xvı, fo. $4^{\mathrm{a}} \mathrm{x}$.)

[53. Benn Boguine.]-Beand Bogaine, cid día ta?

Beand Bogaine . I. bo di bhuaib Flidaisi mna Oililla Find adrullai ind, [f. 4 2] J fiadhaigheastar ann sil na bo sin go rugastar da læg . I. lægh fireand y lægh boineand, go silastar y go fiadhaigsedar ${ }^{1}$ annsin a sil go nach feta ni doib. in tarbh robai aco intan rogeisead dothigdis buar Erenn fua $y$ noreithdís go maidheadh a cridhe. Robi Findchad mac Neill for altrom la hinghin n-Uatha. Luid in bo bai 'na beolo sein fo gheim in tairb isin sliab. Luidh mac Neill ina deghaidh ${ }^{2}$ a buair, y gonais a buair J gonais go slegaib na bu, conaca imbí in martghail sin, con-ebert "is boghuine so", ol se, diamba ${ }^{3}$ Beand Boghuine go so.

Beand Boghuine is de dotha

rocualadar fir is mna,

don martgail[s]e, go lin ngal, rognídh go fir la Findchad.

Benn Boguine, whence is it?

Benn Boguine, to wit, thither escaped a cow of the kine of Flidais, wife of Ailil the Fair, and the offspring of that cow became wild. And the cow brought forth two calves, a male calf and a female calf, and her offspring went wild therein so that nought could be done with them. When the bull they had would bellow (all) the cattle of Ireland would go to him, and run so that their hearts were broken.

Finnchad, son of Niall, was in fosterage with Anè, daughter of Uath. The cow that was feeding him went at the roar of the bull to the mountain. Niall's son (at his foster-mother's command) followed the cattle and killed the kine with spears. And when he saw that ox-slaughter, he said: "This a killing of kine," quoth he. Whence Benn Bogluine, "Peak of Kinekilling," hitherto.

Benn Boguine, hence it is,

Men and women have heard,

From this ox-slaughter, with a number of fights,

Which was wrought truly by Finnchad.

Also in LL. 165 a 45 , and, more fully, in BB. 397 a; H. 55 b; and L. 504 b. Benn Boguine has not, so far as I know, been identified. A man's name Bogaine occurs, LU. 70 b r.

As to Flidais, see LL, 247 a $33-248$ a $\mathrm{rr}$.

[54. Mag Corainn.]-Mag Coraind, cid dia ta? Ni ansa.

Corand cruitire sidhe do Dianche[ch]d, mac in Dag[hd]ai, go roghart sein asa croit Cælcheis do mhuccaibh Dreibrinde. Roraith

1 MS. fiagaigsedar. 2 MS. deghaigh. ${ }^{3}$ MS. ciamba. 
fothuaidh ${ }^{1}$ a niurt a chnamh, roraith a niurt retha læchradh Ollnegmacht' $\mathrm{J}$ a chuanart 'na deghaidh, go rige Ceis Coraind. Unde Ceis [Coraind] y Mag Coraing. Vnde poeta cecinit :

Corand cruitire creachach, $m a c$ in Dagh[d]a dianbhreathach.

ba guirt fri feis dianim sluind ${ }^{2}$

triana chruit go ceis Coraind.

Magh Coraind, whence is it ?

Not hard (to say). Corann, he was harper to the Dagda's son, Dianchécht, and out of his harp he summoned Caelcheis, one of the swine of Drebrenn. Northwards it ran with (all) the strength of its limbs. After it ran the champions of Connaught with (all) their strength of running, their hounds following them as far as Céis Coraind. Whence Céis Coraind and Magh Coraind. Whence (also) a poet sang:

Corand, a plundering harper,

The swift-judging son of Diancecht,

Through his harp to Céis Corann.

Also in LL. 165 a 35 ; BB. 389 a 17 ; H. 47 a; Lec. 494 b; R. I14 b 2 ; Versified, LL. 212 a 14 . See, too, Silva Gadelica, ii, 536.

Ctis Coraind is a hill in the barony of Corran, county of Sligo. Magh Coraind is, I suppose, the plain from which it rises.

Dian-checht was the leech, and the Dagdae was the king, of the Tuatha De Danann, who gave Corand a grant of land for his excellent harping (Tucsat Tuath $D i$. . . ferand diles ar degsheinm, LL. 212 a 16 ).

As to the swine of Drebrenn, see Folk-Lore, iii, 495.

[55. LOCH N-ECHACH.]-Loch n-Eachach, canas rohainmnigheadh?

$\mathrm{Ri}[\mathrm{b}]$ mac Maireada y Echo mac Maireadha dolodar anneas a hIrluachair andis for imirce $\mathrm{J}$ rodeagailset andis og Beluch da Liag. Luidh indalanai siar. I. Eocho for Breogha go rogabh for Brugh $^{3}$ Meic in Og. Doluid sein chucu ir-richt brughad, I a gerran ina laimh, $]$ dlomais doib cona bedis isin Brugh. ${ }^{3}$ Atbertadar fris nad bai acu cumang do imachur in ealma ellaig bai oga gen chaipliu. "Cuiridhsi," ol se, "lan in maighe i taid do eiribb cona n-irsibh ar in gearran sa j beraidh libh go maigin i laigfe foa." Dochodar as iarumh go rangadar Liathmuine. Laighid leo an gerran i suidhiu J dobeir a mun ann, co nderna tobar dhe, go tanic thairsiu, conid e Loch nEachach .x. Eochu in rí $y$ fual a eich roleath ann.

Doluid immorro Rib féin timcheall síar gor' gabh i maigh Fhind:

\footnotetext{
1 MS. fothuaigh.

2 This line is corrupt. In LL. $165^{2}$ it is : rogart in muicc fri séis slaind. ${ }^{3} \mathrm{MS}$. brudh.
} 
ba head on 'Tir Cluichi Midhir y Maic in Og. Luid ${ }^{1}$ fon indas

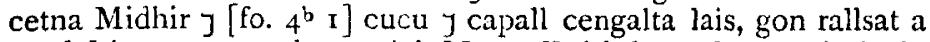
crod fair, gonos-rug leo gorigi Mag nDairbthean forsa ta in loch. Laighid in gerran ann $\mathrm{J}$ dobeir a mhun gor'bo tiprat, gor' muidh tairsib. Ribh ainm in ríg. baiter in Ríb. Unde Loch Ri[bh] J Loch nEchach nominata sunt.

$$
\begin{aligned}
& \text { Baidhis Angus Eocho uais } \\
& \text { tre fhual a eich go n-athluais, } \\
& \text { doluidh Midhir, brigh ron-lean, } \\
& \text { gor' baidh Rib i Maigh Dairbthenn. }
\end{aligned}
$$

Loch $\mathrm{n}$-Echach, whence was it named?

Ríbh, son of Mairid, and Eocho, son of Mairid, the twain went from the south out of Irluachair on a flitting, and separated at Belach dá Liacc, "the Pass of the two Flagstones". One of the twain, even Eocho, went westward on Bregia and set up on the Plain of Mac ind $\mathrm{Oc}: \mathrm{He}$ (the Mac ind $\mathrm{Oc}$ ) went to them in the shape of a land-holder, with his nag in his hand, and told them that they should not bide on the Plain. They said to him that they had no power to carry their load of goods (?) without pack-horses. "Put," says he, "the full of the plain wherein ye stand into bundles with their straps upon this nag, and he will carry them with you to the place where he will lie down thereunder." So they went thence till they reached Liathmuine. Therein the nag lies down beside them, and there he stales, and made of his urine a well which came over them. So that is Loch n-Echach, to wit, Eochu the king and his horse's water, which there spread out.

Howbeit Ríbh himself went around westward and set up on Magh Find : now that was the Playing-ground of Midir and of Mac ind Oc. In the same way Midir went to them, having a haltered horse with him, and they put their wealth upon the horse, and he carried it off with them as far as Magh Dairbthenn, whereon the lake now lies. There the nag lies down and passes his urine until it became a well, which broke over them. Ribh is the king's name. $\mathrm{R}$ íbh is drowned.

Whence Loch Ribh and Loch nEchach were (so) called.

Oengus drowred haughty Echo

By means of his steed's urine, with great speed :

Midir went-force followed him-

And drowned Ríbh on Magh Dairbthenn.

Also in BB. 390 a $3 \mathrm{I}$; H. 49 a and Lec. $496 \mathrm{a}$, where the story is more fully told. Printed, without a translation, in Silva Gadelica, ii, 484, 532. See also Aided Echach maic Maireda, LL. 39 a-39 b, edited by Crowe in 1870 , from which it appears that the "flitting" was an elopement with Eochaid's stepmother Ebliu.

Irluachair, in the south-east of the county of Kerry.

1 MS. Luig. 
Belach da Liacc. Not identified. Breg-mag, a plain in East Meath. Brus (or Mag) Maic ind Oc, the plain through which the Boyne runs.

Liathmuine, " grey brake," somewhere in Ulster.

Loch $n$-Echach, now Lough Neagh, between the counties of Antrim, Londonderry, Down, Armagh, and 'Tyrone.

Oensus, also called Mac ind $O c$, son of the Dagda. See Folk-Lore, iii, 479 .

Midir of Bri J,eith. See Folk-Lore, iii, 493.

[56. Loch n-Érne.]--Loch nÉirne, cid dia ta?

Eirne ingen Buirg Buireadhaigh meic Manchin, banchoimhedaid do chir comraraib Meadbha Cruachan, y bantaiseach ingenraidhe fer Ollnegmacht. Intan iarumh doluidh Olca ái a huaimh Cruachan do chomrag fri Amhairghin Iarghiundach rochroith a ulcha ann doibh [y roben a déta,] go ndeachadar for dasacht macrada ] ingenradha in tiri, go ndernadh a n-aidhead ann ar a omhon. Da reith dano Eirne cona hingenraidh go Loch $\mathrm{nEirne,} \mathrm{go} \mathrm{ros-baidh}$ in loch. Is desin ata Loch nEirne.

Eirne go n-uaill, comoll nglain, inghean Buirg buain Buireadhaich, si rotheich, ni gnim n-uabhair, fo loch Erne ar imuamain.2

Nó ba ferann do Ernaib fecht n-aile go robris Fiacho Labrainne mac Senbotha meic Tighernmais cath forro goros-dílgend, ${ }^{3}$ conidh iarsin do mebhaidh in loch fo tir nErenn. Unde est Loch nEirne, et quod uerius est.

Lough Erne, whence is it?

Erne, daughter of Borg the Bellowing, son of Manchín, was the keeperess of Medb of Cruachu's comb-caskets, and leader of the maidens of the men of Connaught. Now when Olca Ai went out of the cave of Cruachu to contend against Amargen the Black-haired, he shook his beard at them and gnashed his teeth, so that the boys and girls of the country went mad, and their tragical death was caused by dread of him. Then Erne with her maidens ran to Lough Erne, and the lough drowned them. Thence is (the name) Loch $n$-Erne.

Erne with pride, a pure union,

Daughter of good Borg the Bellowing,

She fled-no deed to boast of -

Under Lough Erne for exceeding fear.

Or it [the bed of Lough Erne] was once the territory of the Ernai, until Fiacha Labrainne, son of Senboth, son of Tigernmas, routed them in battle and destroyed them; and thereafter the

1 MS. rochraith a chulcann.

2 In the MS. this quatrain is at the end of the article. ${ }^{3}$ MS. -dligeandh. 
lake burst throughout the land of Erin. Whence is Loch nErne, and this is truer.

The first paragraph is also in BB. $39 \mathrm{ra} \mathrm{r} 8 ; \mathrm{H} .49 \mathrm{~b} ;$ and Lec. $498 \mathrm{a}$.

Loch $n$ Erne, now Lough Erne, in the cuunty of Fermanagh.

$M e d b$ of Cruachu, the famous queen of Connaught.

Amargen, father of Conall Cernach.

[57. Slía B Betha.]-Slíabh Beatha, cidh día ta ?

Bith mac Nai meic Lamhiach $]$ Cessair ingen Betha $y$ Iadru a luamh y Findtan mac Bochra a maccæm dolodar for teicheadh cethrachad laithi ria ndilind fodeigh doruimenadar na badh do airimh in betha in t-innserad iartharach don bith o muir Thorrian ${ }^{1}$ siar, J asbert $\mathrm{Næ}$ mac Lambiach nis-leicfeadh son i n-airc. Dolodar a ceathair ar imgabhail na dilend sin go torachtadar Erinn $\mathrm{J}$ ros-baidh in dili amail dos-tarraidh in gach aird .r. Bith $\mathrm{i}$ Slíabh Betha, Ladru i nArd Ladrann, Cessair i Cuil Cessra, Finntan. i Fert Findtain os Tul Tuinde. Robi bliadın lan i mbadhud conid iarum ron-athnai arisi, $J$ in barc $\mathrm{i}$ tudchadar ${ }^{2}$ isi go mbrui in lear imon carraig ig Iun Barc iarna dusgudh a huisci dia cind' bliadne. Unde Sli-[fo. $4^{\mathrm{b}} 2$ ]-ab Beatha.

$$
\begin{aligned}
& \text { Rofhuair Bit[h] bas forsin } \mathrm{t}[\mathrm{s}] \text { leib } \\
& \text { mac Lamhíach luchair lainfeil, } \\
& \text { rombaidh }{ }^{3} \text { in dili dedla } \\
& \text { ua Malalein mor echta. }
\end{aligned}
$$

Sliab Betha, whence is it?

Bith, son of Noah, son of Lamech, and Cessair, Bith's daughter, and Ladru his pilot, and Finntan, son of Bochra, his boy, went in flight, forty days before the Deluge, because they thought that the western islands of the world, from the Tyrrhene sea westward, would not be counted as belonging to the world, and Noah, son of Lamech, had said that he would not let them into the ark. To avoid that flood the four fared on till they reached Erin, and the Flood drowned them as it overtook them at each point, to wit, Bith on Sliab Betha, Ladru on Ard Ladrann, Cessair in Cúil Cessra, and Finntan in Fert Finntain over Tul Tuinne. (Each) was for a whole year beneath the waves, ${ }^{4}$ and then (the sea) gave them up again; but as to the ship wherein they had arrived the sea dashed it on a rock at Dún Barc on the last day of the year after it had been raised out of the water. Whence is Sliab Betha.

Bith found death on the mountain.

(Bith), son [leg. grandson ?] of Lamech the bright, fullyhospitable,

\footnotetext{
1 MS. thorrian.

MS. tudchaidhar.

4 Literally, "in drowning."

vor. IV.

3 MS. rombaigh.

K K
} 
The bold Flood drowned him, The grandson of great-deeded Methusalem.

The corresponding story in BB. 397 b $18 ;$ H. 56 b; and Lec. 505 a, is much briefer. Keating (p. IO7 of O'Mahony's version) gives a tale more nearly resembling ours. See also BB. 22 b, and the Four Masters, A.M. 2242.

Sliab Betha, "Bith's Mountain," now Slieve Beagh, a mountain on the confines of Fermanagh and Monaghan.

Ard Ladrann, somewhere on the sea-coast of the co. Wexford.

Cuil Cessra. "Cessair's Recess," said to be Coolcasragh, near Knockmea, in the co. of Clare. In BB. 22 b I5, we have Ceassair o ta Carn Cuili Ceasrac $i$ Connachtaibh; but see O'Donovan's note $h$, Four Masters, A.M. 2242.

Fert Finntain." "Finntan's Grave," in the territory of Lough Derg.

Dún Barc, also Dun na mbarc, now Dunamark, in the barony of Bantry and counity of Cork.

[58. Colre mBrecCálN.]-Coire mBrecan, can as rohainmniged?

Brecan mac Partholoin dochuaidh ar uaill $\mathrm{j}$ ingaire go tríun sloig Erenn umi fo chumcha inbeatha for dimus. Is eadh leath rola, forsin fairrgi mbaileadhaigh fothuaidh, ${ }^{1}$ gorige in sæbchoiri, ] go robaidhead ann, conid de ata Coire mBrecain.

Mac Parrtholoin, gnim gen gloir, rof húair samthoghail ${ }^{2}$ sirbroin.

Brecan na læchraidhe ille ron-sluig sæbhchoire suighthe. ${ }^{3}$

Nó gomad Brecan mac Maine meic Neill robaidhedh ann. Is e a asna adracht fo churach Coluim chilli dia ndebert: "Is condalbh sin, a shen-Brecain," et quod est uerius.

Coire mBreccain, whence was it named?

Breccan, son of Partholan, went, for pride and impiety (?), with a third of the host of Erin around him, throughout the world's straits. This is the direction in which he went, northwards over the furious sea, as far as the whirlpool (so called), and there he was drowned. So thence is the name Coire mBreccáin, "Breccán's Caldron."

Partholan's són, deed without glory,

Found a very mournful destruction.

Breccán of the heroes hither,

A whirlpool sucking down swallowed him.

Or it may be that Breccán, son of Maine, son of Niall (of the Nine Hostages), was drowned therein. It is his rib that rose up under Colomb cille's boat, when the saint said : "That is friendly, thou old Breccán," and this is truer.

Similar tales are in BB. 398 a, and Lec. 505 b. They are translated in Reeves' Vita Columbae, pp. 262, 263. See also Cormac's Glossary, s.' v. Coire Brecain.

The Coire $m$ Breccain here mentioned is, according to Reeves, the dangerous sed

1 MS. fothuaigh. ${ }^{2}$ MS. samhthodhail. ${ }^{3}$ ln the MS. this
quatrain is at the end of the article.


between Rathlin Island and the north coast of Ireland, and not the strait between Scarba and Jura, which is now called Corryvreckan, Vita Columbae, pp. 29, 121. As to Partholan, see LL. 127 a, and O'Mahony's Keating, pp. 83, 114-ri6.

[59. BENN FOIBN1.]-Beann Foibhne, can as rohainmnigheadh? Ni ansa.

Foibne feinnidh, is e rombuail Illand mac Erclaim ${ }^{1}$ meic Doithre for lar Temrach os gualaind Eachach Ailtleathain meic Ailella Caisfhiaclaich. Luidh iarum fothuaidh ${ }^{2}$ arfud Breag. Roslac Feargna Fear Ga[i] Leatha[i]n ina dhiaidh, $J$ immusracht $^{3}$ remhi as gach beinn in-aroile go riacht in beind ud, conidh ann $\sin$ rodoimeart. Unde Bean Foibhne.
Foibhne feinnidh, fuachdha in fear, luidh o Themhraigh i tír mBreagh. i cinaidh Illaind na $n$-ead rombi Fearghna, ba frithbhed.

Benn Foibni, whence was it named?

Not hard (to say). Foibne the champion, 'tis he who struck Illann, son of Erclam, son of Doithre (the king of Sliab Moduirn), in the midst of Tara, above the shoulder of Eochaid of the Broad Joints, son of Ailill of the Twisted Teeth. Then he went northward throughout Bregia. Fergna Fer Gái Leathain, "the Man of the Broad Spear," hurled himself after him, and drove Foibne before him from one peak to another, till he reached that peak, and there Fergna killed him. Whence Benn Foibni, "Foibne's Peak."

Foibne the champion, surly was the man,

Went from Tara into the land of Bregia.

In revenge for Illann of the jealousies

Fergna slew him-'twas a counter-hurt.

Also in BB. 399 a ; H. 57 b ; Lec. 506 b.

Benn Foibni has not been identified.

Foibne is described in the other MSS. as Eochaid Altlethan's cupbearer (deogbaire).

Eochaid Altlethan, said to have been over-king of Ireland from A.M. 4788 to A.M. 4804 , as was his father, Ailill Casf hiaclach, from A.M. $475^{8}$ to A.M. 4782 .

[60. Ard Fothaid.]-Ard Fothaidh, ${ }^{4}$ cid dia ta? Ni ansa.

Fothadh gonatuil ann go ceand nai mis fri foghur circi Boirci dia mbai for a echtra. Unde Ard Fothaid.

1 MS. is e rombai il laim lam. 2 MS. fothuaigh. ${ }^{3}$ MS. imriacht, but $\mathrm{BB}$. has imusracht, and $\mathrm{H}$. has musracht.

MS. fothaigh. 


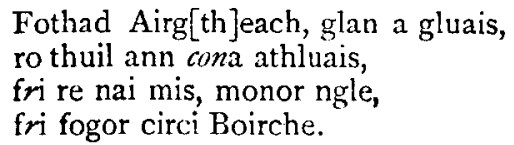

Ard Fothaid, whence is it?

Not hard (to say). Fothad slept there till the end of nine months at the sound of Boirche's hen, when he was on his adventure. Whence is Ard Fothaid, "Fothad's Height."

Fothad Airgthech, clear his movement, Slept there with his great speed.

For nine months' space, brilliant deed, At the sound of Boirche's hen.

\footnotetext{
Also in BB. 399 a 32 ; H. $5^{8}$ a ; Jec. 506 b; and Rennes \pm 16 a 2, where the " nine months" is reduced to "three fortnights". See, too, Silva Gadelica. ii, 53 I.

Ard Fothaid. This seems the same as the Ard Fothadh of the Four Masters, A.D. 639 ." "the nanie of a fort on a hill near Ballymagrorty .... in the co. of Donegal" (?). See also Reeves, Vita Columbae, p. 38, note. it is spelt Ard Fothaid in the Tripartite Life, Rolls ed., p. 148, and Ardd Fothid in the Book of Armagh, fo. $18 \mathrm{~b} 2$.

Fothad Airgthech, a son of Mac-con, was slain in battle A.D. 285. There is a story about the identification of his tomb in L.U. $133 \mathrm{~b}$, which is printed and translated in Petrie's Round Toners, pp. 107, 108. The allusion to Boirche's hen is to me obscure.
}

\section{[6r. Ard Macha.]-Ard Macha, cid dia ta? Ni ansa.}

Macha ben Nemidh meic Agnomain atbath ann, $y$ ba he in dara magh deg roslecht la Nemhead, J do breatha dia mhnai go mbeith a ainm uasa, $J$ is $i$ adchonnairc $i$-aislinge foda reimhe a techt ina ndernad do ulc im Thain bho Cuailngi ina cotludh tarfas di uile ann rocesad do ulc and do droibhelaib $y$ do midhrennaib, go romhuidh a cridhe inti. Unde Ard Macha.

Nó Macha ingen Edha Ruaidh meic Baduirnn, is le rotoirneadh Eo-[fo. $\left.5^{a} 1\right]$-muin ${ }^{1}$ Macha, $]$ is and roadnacht día ros-marbh Rechtaid² Rígderg, is dia gubhu rognídh ænach Macha. Unde Macha magh.

Ailiter, Macha dano bean Cruind meic Agnomhain doriacht ann do comrith ann ri heocho Conchobair, ar atbert a fear ba luathe a bean inaid na heocho. Amlaidh dano bai in bean sin, inbhadach, go ro chuindigh cairde go ro thæd abru, $]$ ní tugadh di, $]$ dogní in comhrith iarum $\mathrm{J}$ ba luaithiamh si, $\mathrm{J}$ o roshiacht cend in chede berid mac y ingin, Fir y Fíal a n-anmann, y atbert go mbeidis Ulaidh fo cheas $^{3}$ oitedh in gach uair dos-figead eigin, conid de baf in cheas for Ultu fri re nomaide 4 o re Conchobhair go flaith Mail meic Rocraide, J adberar ba si Grian Banchure ingean Midhir Bri Léith, J

1 MS. imui. ${ }^{2}$ MS. rosumarb rechtaig. ${ }^{3}$ MS. inserts J. ${ }^{4}$ MS. xxde. 
adbeb iar suidhiu $\mathrm{J}$ focreas a fert i nArd Macha, $J$ focer a gubha, J roclannad a lía. Unde Ard Macha.
Atchonnairc Macha marglic
tri fhis, ratha na raidmid, tuirthechta trimsa Cuailghne
fa gnim ndimsa nimuaibre.

Ard Macha, whence is it?

Not hard (to say). Macha, wife of Nemed, son of Agnoman, died there, and it was the twelfth plain which was cleared by Nemed, and it was bestowed on his wife that her name might be over it, and 'tis she that saw in a dream, long before it came to pass, all the evil that was done in the Driving of the Kine of Cualnge. In her sleep there was shown to her all the evil that was suffered therein, and the hardships and the wicked quarrels : so that her heart broke in her. Whence Ard Macha, "Macha's Height."

$$
\begin{aligned}
& \text { Macha, the very shrewd, beheld } \\
& \text { Through a vision-graces which we say not- } \\
& \text { Descriptions of the times (?) of Cualgne- } \\
& \text { Twas a deed of pride, not of boasting. }
\end{aligned}
$$

Or, Macha, daughter of Aed the Red, son of Badurn: 'tis by her that Emain Macha was marked out, and there she was buried when Rechtaid Red-arm killed her. To lament her Oenach Macha, "Macha's Assembly," was held. Whence Macha Magh.

Aliter. Macha, now, wife of Crunn, son of Agnoman, came there to run against the horses of King Conor. For her husband had declared that his wife was swifter than the horses. Thus then was that woman pregnant: so she asked a respite till her womb had fallen, and this was not granted to her. So then she ran the race, and she was the swiftest. And when she reached the end of the green she brings forth a boy and a girl-Fír and Fial were their names-and she said that the Ulaid would abide under debility of childbed whensoever need should befall them. So thence was the debility on the Ulaid for the space of five days and four nights (at a time) from the era of Conor to the reign of Mál, son of Rochraide (A.D. 107). And 'tis said that she was Grian Banchure, "the Sun of Womanfolk," daughter of Midir of Bri Léith. And after this she died, and her tomb was raised on Ard Macha, and her lamentation was made, and her pillar-stone was planted. Whence is Ard Macha, "Macha's Height."

\footnotetext{
Also in BB. 400 b $49 ;$ H. 6r b; Lec. 5 IO b; and R. II7 b r. But none of these copies contain the account of the first Macha's dream, or the quatrain referring thereto. That the second Macha marked out Emain is told also in Cormac's Glossary, and LL. $20 \mathrm{~b} 48$. The story of the third Macha's race with Conor's horses, and of the birth of her twins, is related more fully in LL. 125 b 42 , whence it has been published by the late Sir Samuel Ferguson in a note to his Congal, pp. 189, 190, with a Latin version, and by Prof. Windisch in the Berichte of the Royal Saxon Gesellschaft der Wissenschaften, 1884, pp. 336-347, with a German translation.
} 
[62. Mag CoвA.]-Mag Coba, cid día ta? Ni ansa.

Mag Coba cuthchaire. Nó Coba cuthchaire feisin .x. cuthchaire Eremoin meic Mileadh, is e cétna roindlestair cuithigh $\mathrm{i}$ nErinn. Atnaigh a chois indi dus in bad doith ina cuithigh, go romuidh buinde a sliasta $\mathrm{J}$ a da dhoid, con-ablad de. Is de sin ata Mag Cobha. Unde poeta dixit :

Cobha cuthcaire go ngloir ardri[g] Erend Eremhoin, is e rosdeadhlad de

Coba cennmhar cuthchaire.

Mag Coba, whence is it?

Not hard to say. The plain of Coba the pitfall-maker. Or, Coba the pitfall-maker himself, that is, the pitfall-maker of Eremon, son of Míl. He first in Erin arranged a pitfall. And he put his foot into it to see whether it was ... in his pitfall, whereupon his thighbone (?) broke, and his two forearms, so that he died thereof. Thence is $M a g C o b a$, and hence the poet said :

Coba the glorious pitfall-maker,

Of Erin's over-king Eremon :

'Tis he that would sever himself from him,

Great-headed Coba the pitfall-maker.

Also in BB. 400 b 34 ; H. 6r b; Lec. 510 b; and Kennes riz a 2.

Mag Coba seems to have been the old name for a portion of the baronies of Iveagh in Ulster. Sce Reeves, Eccl. Antiquities of Dou'n. Conor, and Dromore, p. 349, where cuthchaire is misrendered by "huntsman".

As to Eremon, son of Mil, see the Four Masters, A.M. 3501, and infra, No. 76.

[63. Sliab Catllainn.]-Sliab Kallan, cid dia ta? Ni ansa.

Callann conbhuachaill Buidhe meic Bain blaidh meic Forgamhna forobar[t] in Don $n$ Cuailghni in mi riana re coir .x. dairi in$t[s]$ easgraidhi imbi forrobartar $]$ in cu [oc cosnam in tsescraigh co torcair in cu di sodain- $B B$.] Nó gomadh ig tabairt na tana comcomult in choin arin talamh. Unde Sliab Kalland.

Calland conbhuachaill crethaigh [leg. crethaidh ?]

Buidhe mac Bain bithbreathaig.

glecais frissin nDonn Cuailghne

ba forlonn fri heduailghne [leg. étuailngi ?].

Sliab Callann, whence is it?

Not hard (to say). Callann the sheep-dog of Buide, son of Ban blaith, son of Forgamuin. The Donn of Cualgne, the month before his proper time, proceeded to bull the dry cows around him. He and the dog began to contend for the dry cows, till the dog fell by him. Or it may be that at the taking the drove he crushed the dog on the ground. Whence Sliab Callann. 


\author{
Callann, the skilful (?) sheep-dog \\ Of Buide, son of ever-judging Ban, \\ Fought with the Brown Bull of Cualgne. \\ $\mathrm{He}$ was savage at wrong.
}

\begin{abstract}
Also in BB. 404 b I ; H. 64 b; Lec. $5 I_{4}$ b; and R. IIg b 2, where there is an additional paragraph stating that the dog was a pup of Daol, the hound of Celtchar, which had been found in the skull of Conganchnes ("Hornskin"), along with the hounds of Culann the Brazier and Mac dá Tho. As to this see the note in the left margin of LU. $6 \mathrm{x}$ a.

The Edinburgh codex is here so corrupt and incomplete that I have not ventured to punctuate, and my version is merely tentative.

Sliab Callann is now Slieve Gallion, a mountain in the county of Londonderry. on the borders of Tyrone.

The Donn of Cualgne (now Cooley in the co. of Louth) is the famous brown bull to obtain which was the object of the expedition known as the Tain $b \delta$ Cualngi, "Driving of the kine of Cualnge."
\end{abstract}

[64. Sliab Fuait.] -Sliab Fuait, canas rohainmniged?

Fuad mac Bile meic Breoghain, is é robo rí Ua mBreoghain. Taraill inse ${ }^{1}$ ar in fairrge [oc tuidecht la macaib Miled] dochum nErend, J gach æn nofuirmheadh a bond fuirri ni abrad gaí nó breig. Tug fod fírindi lais [fo. $5^{\mathrm{a}} 2$ ] asin indsi. intan adbereadh gai dochuiredh ${ }^{2}$ a fæsgul suas, $]$ intan atberead firindi dochuireadh a chain suas. Ata in fod sin isin tshleib beus, $]$ is fair dorochair in graindi $o$ gherran Padraic, conidh adrad sruith[i] ardaigh na firinde do choimhet. Unde Sliabh Fuait.

Nó gomad in [leg. on] fod doradad for Ceand mBerridi do imarchur, ar rothairgsead Ulaid righe don ænf hir noberadh corp Conchobhair go hEamain oda Mag Lamhraidhe gen fhuirmeadh, go rogabh Ceann Berride fair, go roisead Sliabh Fuait, go tard a bonn fri lár i Sleib Fuait. Adbertadar Ulaid na bad rí aire sin e. Atbert som fod go leithead a bonn do thabairt fair. Doradadh on go roacht Emhain. Conid ann dobhath, conidh desin ata "righe Chind Berride".

$$
\begin{aligned}
& \text { Fuat mac Bile chæimh cruadhaigh, } \\
& \text { ua Breaguin buirr bithbuadaig, } \\
& \text { tuc ar rod fear luchta ille } \\
& \text { fod fors'tuc[tha] firinde. }
\end{aligned}
$$

Sliab Fuait, whence was it named?

Fuat, son of Bile, son of Breogan, 'tis he that was king of Húi lireogain. As he was coming to Erin with the sons of Mil he landed on an island in the ocean, and no one who set his sole thereon would utter a lie or a falsehood. Out of the island he brought a fót (sod) of truth, whereon he sat when dealing doom and deciding questions. When he uttered falsehood it would put

1 For inse the MS. has (corruptly) for in fairgecht. MS. inserts: a chain suas ata in fod.

4 MS. bithbuagaig.

3 Here the 3 MS. cruaghaigh. 
its earthy side upwards, and when he uttered truth it would put its grassy side upwards. That sod is still on the mountain, and tis on it the single grain fell from St. Patrick's nag. Wherefore sages honour it because of preserving the truth.

Or it may be from the fot (sod) which was put upon Cenn Berridi to be carried; for the Ulaid had promised the realm to the one man who should carry (King) Conor's corpse from Magh Lamraide to Emain without laying it down. So Cenn Berridi took it up and reached Sliab Fuait, and on Sliab Fuait he put his sole to the ground. For that reason the Ulaid declared that he should not be king. He told them to put upon him a sod as broad as his sole. This was done, and he got to Emain, but there he (straightway) died. Whence is (the proverb), "Cenn Berride's Kingdom."

Fuat, son of dear hardy Bile,

Grandson of rough, ever-victorious Breogan, The man of the burden brought hither on a road A sod whereon truth was put.

Also in BB. 404 a 31 ; Lec. $5 I_{4} \mathrm{a}$; and R. IIg b 2, where the name of the island is given as Inis Magdena, or MLagdeda, id est mor, og, diada, "great, perfect, divine"; and where the mountain's name is also derived from that of Fuat. See also Silva Gadelica, ii, $52 \mathrm{I}$.

H. adds the story of Cenn Berridhe. See as to this LL. 124 a 32-37, and O'Mahony's Keating, p. 273.

Emain, now the Navan Fort, near Armagh. Sliab Fuait, a mountain near Newtown Hamilton, in the county of Armagh.

Other ancient Irish ordeals are described in Irische Texte, 3. Serie, I Heft, pp. 185 et seq.

The story of the grain of wheat is told in the Tripartite Life, Rolls ed., p. 240.

[65. Lia LindGaLAin.]-Lia Lindghadain, cid dia ta?

Li[ngadan Labar, issé no chosced slú]agh Erenn i flaith Find meic Findtain, $\mathrm{J}$ ni lamtha labhrad leis for muir na for tír gan farfaighidh do son, ar is e robo sluag-rechtaire fer nErenn. Rolabrasdar fecht n-and fria di chulaidh asin carraig [in] mac alla a gotha. Imsai ${ }^{1}$ fris anall do dhighail a gotha fair. Dan-arraidh barr ${ }^{2}$ na murthuinde $y$ ran-esart frisin carraig, conidh romarbh fodiadh. $^{3}$ is and bai ceand a shæghail. Unde dictum est:

Linga labor, fear go mblaid,
robai i n-aimsir Fhindtain.
rofæn in[fh]airrgi go foll
ria thæbh chairrgi gan chomhlaind.

Lia Lingadain, whence is it?

Lingadan the Arrogant, 'tis he that used to control the host of Erin in the reign of Find, son of Finntan, and no one durst

${ }^{1}$ MS. imrai. ${ }^{2}$ MS. danearraidh bara. ${ }^{3}$ MS. fodiagh. 
speak with him, on sea or on land, without being asked by him, for he was the host-steward of the men of Erin. Once upon a time the echo of his (own) voice spoke out of the crag behind him. He turned towards it to take vengeance upon it for speaking, and the crest of the sea-wave overtook him and dashed him against the crag, so that, finally, he died. There was the end of his life. Whence was said :

Linga the Arrogant, a man with fame,

Lived in the time of Finntan,

The sea threw him backwards violently, ${ }^{1}$

Against the side of a crag, without conflict.

Also in LL. 165 b 25 ; BB. 407 b 3 ; H. (I omitted to note the page); and Lec. $519 \mathrm{~b}$.

Of "Find, son of Finntan", I know nothing.

[66. Mag Mugna.]-Magh Mughna, canas rohainmnigheadh?

Maighnia nó Mairgnia .r. morgnimh feadha daurbhile mora roasai ann, comtír coimhleathna a mbarr frissin magh. teora toirthi fodocheardais in gach bliadain [.1. dearcain J ubla $\mathrm{y}$ cnai.] Intan dothuitead in dearcu dedhenach is and nof hasadh blaith na ce[t]dercan dib, conth taibhdeisdear Ninne eigeas, go ro leagh riamh condergan ailind de . 1 . nith nemhannach, $y$ is desin ata Magh Mugna.

\author{
Mughna durbhile gan on \\ forsa mbid meas is torudh. \\ ba comhleathan a barr becht \\ frisin magh mor gan eigeart .I. aine orda.
}

Mag Mughna, whence was it named?

Maighnia or mair-gnia, "great sister's son," to wit, a great deed. Here there is a lacuna.

Woods, great oak-trees grew there, so that their tops were as broad as the plain. Three fruits they used to yield in every year, to wit, acorns and apples, and nuts. When the last acorn fell, then the blossom of the first of these acorns would grow, so that Ninine the poet .......

and thence is Magh Mugna.

Mughna's oak-tree without blemish,

Whereon were mast and fruit,

Its top was as broad precisely

As the great plain without ....

Also in BB. 368 b 26 ; H. 23 a ; Lec. $466 \mathrm{a}$; and R. Ior b. All the copies are obscure, and the Edinburgh copy is incomplete.

In a note to the Calendar of Oengus, Dec. Ir, Mugna is said to have been a

1 This line is a mere guess. I take rofaen to be $3 \mathrm{rd} \mathrm{sg}$. pret. of a denominative from faen $=$ Lat. supinus, and foll to be oll .1. mór $\left(\mathrm{O}^{\prime} \mathrm{Cl}\right.$.), with prothetic $f$. The compar. $f$-ulliu occurs in LU. $22^{\mathrm{b}} 4 \mathrm{O}$. 
trce 30 cubits in girth and 300 cubits in height, which bore fruit thrice a year, and remained hidden from the Deluge till the birth of Conn of the Hundred Battles. And in LL. 200a 12, we read that it fell southwards over Mag n-Ailbi, that it bore 900 sacks of acorns, and yielded three crops every year-" apples, wonderful, marvellous ; nuts, round, blood-red ; and acorns, brown, ridgy.

[67. Findloch Cera.]-[fo. $5^{\text {b }}$ I] Find loch Cera, cid dia ta? Ni ansa.

Enlaith tiri tairngiri dodheachadar and do fhailte fri Padraig dia mbai i Cruaich Aigle. Rofearsat gles forsin loch goma findithir lemnacht, $\mathrm{J}$ rochansat ceol ann gen bhai Padraic forsin cruaich. Conidh de sin ata Findloch Ceara. Doluidhset tar muir alle enlaith tire tairngire gor gellsad in loch darlibh $\mathrm{i}$ coindi Padraig portghil.

Findloch ["White Lake"] of Cera, whence is it ?

Not hard (to say). A flock of birds of the Land of Promise came there to welcome St. Patrick when he was on Cruach Aigle. They struck the lake (with their wings) till it was white as new milk, and they sang music there so long as Patrick remained on the Cruach. So thence is Findloch ("White-lake") of Cera. The birds of the Land of Promise fared hither over sea. . . . .

Also in H. 44 b; Lec. 487 a ; and R. 112 b 2. Versified LL. 158 b. The last sentence I cannot translate.

Findloch Cera, now Lough Carra, in the co. of Mayo.

The Land of Promise, one of the Irish names for Fairyland.

Cruach Aigle, now Croaghpatrick in Connaught.

[68. Mag Tallien.]-Mag Tailden, cid dia ta? Ni ansa.

Tailltiu inghen Maghmhoir rig Espaine, ben Eachach Gairbh meic Duach Teimhin. Ba si mumi Loga meic Eithleann, $\mathrm{J}$ isi roclaidheadh in magh. $N o$ is and atbath. Dia taide fogumhair roladh a fert $y$ doronadh a gubha $y$ roacht $\mathrm{a}^{1}$ nasad la Lugh [unde Lugnasa(d) dicimus. Coic cet bliadan immorro $]$ mili ria ngein Crist andsin, J nognithe ind ænach la cach ríg nogeibed Eiri co tainic Patraic, $y$ coic cet aenach i Tailltin o Patraic co Duboenach Dondchada (meic Flaind) meic Mail-sechlainn]. Ocus it e teora gesa Tailtean : techt tairse gen tairleim, a deagsain tara ghualaind clf ig taidhecht $t^{2}$ uaithi, faisdibhrugudh fuirri iar fuineadh ngreine. Unde Magh Tailten.

Tailltiu ingean Magmhoir mhoill, is $i$ sin ro ben in choill, bumi Logha luaidhit fir, baile in teidi-sea im Thailltin.

Mag Tailten, whence'is it ?

Not hard (to say). Tailltiu, daughter of Maghmor, King of 
Spain, wife of Eochaid the Rough, son of Dua the Dark-grey. She was Lugh mac Ethlenn's foster-mother, and 'tis she that used to dig the plain.' Or 'tis there that she died. On the first day of autumn her tomb was built, and her lamentation was made and her funeral game was held by Lugh [whence we say Lughnasadh, "Lammastide". Five hundred years and a thousand before Christ's birth was that, and that assembly was held by every king who took Ireland until Patrick came, and there were five hundred assemblies in Tailtiu from Patrick down to the Black Assembly of Donnchad, son of Flann, son of Maelsechlainn]. And these are the three tabus of Tailtiu : crossing it without alighting; looking at it over one's left shoulder when coming from it; idly casting at it after sunset. Whence Magh Tailten, "Taltiu's Plain."

Taltiu, slow Magmor's daughter,

'Tis she that cut down the forest.

Lugh's foster-mother, men declare,

The place of this assembly (is) round Tailtiu.

\begin{abstract}
Also in BB. 403 a $30 ; H, 10 \mathrm{~b}$; Lec. 513 a; and R. I19 a $x$, from which the words in brackets have been taken. See also Silva Gadelica, ii, $5{ }^{14}$.

Tailtiu, now Teltown, in Meath. For traditions relating to the assembly or fair held there, see O'Mahony's Keating, p. 30r, and the Four Masters, A.M. 3370.

The above etymology of lughnasadh is also in Cormac's Glossary.

Donnchad, son of Flann Sinna, son of Mael-shechlainn, was over-king of Ireland from A.D. 9 r 8 to A.D. 942 . The "Black Assembly" means, perhaps, the assembly which, in A. D. 925, was prevented by Muirchertach, son of Niall.
\end{abstract}

[69. Benn Bairchi.]-Beand Bairchi, cidh dia ta? Ni ansa. .x. Bairche boaire Rosa Ruaidhbuidhi, ba headh a shuidhi mbuachalla, in bheand, $J$ is cuma argairead gach mboin oda Dun Sobairce go rige in mBoaind, $]$ ni geilead mil dib mír foroil seach araile, conaidh desin ata Beand Bairchi, amail asbert :
Bairchi boaire gu mbladh ${ }^{2}$
baí ag Rosa [leg. Ross] Ruadh roneartmhar
in beand, nach tlaith re duba,
a suidhi blaith buachalla.

Benn Bairchi, whence is it?

Not hard (to say). Bairche, Ross Ruddy-yellow's cowherd, this was his herdsman's seat, the Benn, and (there) equally would he herd every cow from Dunseverick to the Boyne : and no (one) beast of them would graze a bit in excess of another. So thence is Benn Bairchi, "Bairche's Peak," as said (the poet) :

1 I.e., to dig up the roots of the trees with which the plain was
covered.
MS. mblaidh. covered. 
Bairche, the famous cowherd, Who belonged to very mighty Ross the Red: The peak was the soft seat of the herdsman, Who was not weak against sadness.

Also in BR. 403 a; H. 64 a ; Lec. 512 b; and R. 118 b 2. See also Silva Gad'tica, ii, 527 . BH., H., and Lec. add the following:

Aliter, Bennan mac mBricc, hind romarb Ibel mac Mianannan i ndul coa mhnai .r. Leccon ingren Lodair a hainm sen, conid he sin fath darroleic Manannan a tri Jommand cumad dia cridiu . I. Loch kuide. Loch Cuan, I wch Dachaech, 7 romarb Bendan iarsin for a benn ut. Unde Benn Bennain dicitur.

"Otherwise: Bennan, son of Brec : thereon he killed Ibel, son of Manannan, for going to his wife, whose name was Leccon, daughter of Lodar. So this was the cause why Manannan cast from his heart his three draughts of grief, (which became) Loch Ruide, Strangford Lough, Waterford Harbour. And he afterwards killed Bennan on yon peak. Hence it is called Benn Bennain, "IBennan's Peak."

Beanna Boirche, the Peaks of Boirche, "is still applied to that part of the Mourne Mountains, in the county of Down, in which the river Bann has its source," Fuz Hater.s, r493, note $j$

Loch Ruide not identified

Kors Ruad-buide (or Rigbuide, "yellow-forearmed"), King of Ulaid in the third century.

[70. Traig Tuirbi.]-Traig Tuirbe, cidh dia ta? Ni ansa.

Turbe Traghmar, athair Gobain sair, [is e rodon-seilb. Is on forbbai $-B B$.] is e focheirdeadh a urchur dia biail ${ }^{1} \mathrm{i}^{2}$ Telaigh Bela inaghaidh in tuile, co $n$-ergaradh in fairrgi [] ni tuidchead tairis$B B$.$] . Ocus ni feas a geinelach { }^{3}$ acht masa dinibh teasbadhchaibh xesa dana atrulliath a Temraigh ria Sam-ildanach fail i ndiamraib Breagh. Unde Traig Tuirbe.

\section{'Tuirbe trágmar ${ }^{4}$ ba fear feimh, 5 athair Gobain go nglainmhein, ni fes a geinelach ${ }^{6}$ gle: uad ainmnigther Traig Turbe.}

Tráig Tuirbi, whence is it ?

Not hard (to say). Tuirbe Trágmar, father of Gobbán the Wright, 'tis he that owned it. "Tis from that heritage he, (standing) on Telach Bela ("the Hill of the Axe"), would hurl a cast of his axe in the face of the floodtide, so that he forbade the sea, which then would not come over the axe. And his pedigree is not known, unless he be one of the defectives of the men of art who fled out of Tara before Samildánach, (and whose posterity) is in the secret parts of Bregia. Whence Traig Tuirbi, "Turbe's Strand."

${ }^{1}$ MS. biailli. ${ }^{2}$ MS. ai. $\quad{ }^{3}$ MS. geinedhlach. ${ }^{5}$ feimh [leg. féimh ?] negligent, neglectful, O'Reilly. geineadhlach.

MS. tradmar. MS. 


\section{The Edinburgh Dinnshenchas.}

Tuirbe Trágmar was a negligent man,

Father of Gobbán with pure desire.

Unknown is his bright pedigree,

lirom him Tráig Tuirbi is named.

Also in BB. 408 b; H. 68 a ; Lec. $520 \mathrm{~b}$; and R. 124 b x. See also Petrie's Round Towers, pp. 382, 383; O'Curry's Manners and Customs, iii, $4 \mathrm{I}$; and O'Grady's Silva Gadelica, ii, 518.

According to Petrie, Triig Tuirbi is now Turvey, on the northern coast of the co. of Dublin, and the Diamra Breagh are now Diamor in Meath.

The Gobbin Saer was an architect who flourished (according to Petrie) early in the stventh century.

Samildknach. "skilled-in-many-arts-together," $\sigma \nu \mu \pi \sigma \lambda u ́ \tau \in \chi \nu o s$, if one may coin a Greek word, was a name for Lugh mac Ethlenn. See "The Second Battle of Moytura", Rev. Celtique, xii, pp. 74, 76, 78, 80.

The tale of Tuirbe and his axe is a tolerably close parallel to that of Paraçurama. "This hero, after the destruction of the Kshatriya race, bestowed the earth upon the Brâhmans, who repaid the obligation by banishing him as a homicide from amongst them. Being thus at a loss for a domicile, he solicited one of the ocean, and its regent-deity consented to yield him as much land as he could hurl his battle-axe ${ }^{1}$ along. Paraçurâma threw the weapon from Gokernam to Kumari, and the retiring occan yielded him the coast of Malabar, below the latitude of $15^{\circ}, " \mathrm{H}$. H. Wilson, Catalogue of the Mackensie Collection, and ed., Madras, 1882 , p. 56.

So in his Cilossury of Judicial and Revenue Terms, I.ondon, 1855, p. 40I : "PARAÇURAMA .... An avatar of Vishnu, to whom is ascribed the recovery from the sea of Kerala, or Malabar, by casting his axe from a point of the coast, Mount Dilli .... to the extreme south; the sea retiring from the part over which the axe flew."

[7 I. LusmaG.]-Lusmag, cid dia ta? Ni ansa.

IS as tug Diancecht gach lus n-íce conammalt $a^{2}$ thiprait Slain[gi i n-Achad Abla] fri Mag Tuired aniarthuaith, intan bai cath etir Tuatha De Danann [fo. $5^{b}$ ] ] Fomhoire. [Gach aen do Thuathaib De Danann no laigtis fon lind lusraid sin atraiged slemun slancrechtac $[\mathrm{h}]-B B$.$] Unde Lusmag.$

Diancecht dorat leis alle

gach lus o Lusmhaigh luaidhe [leg. luaighne?],

go tiprait na slainti suaill

f $r$ Magh Tuiread aniarthuaidh. ${ }^{3}$

Lusmag, whence is it?

Not hard (to say). 'Tis thence that Diancecht brought every herb of healing and grated them on Slainge's Well in Achad Abla, north-west of Moytura, when there was a battle between the Tuatha De Danann and the Fomorians. Every one of the Tuatha De Danann whom they would lay under that water of herbs would arise smooth and healed of his wounds. Whence Lusmag, "Herb-plain."

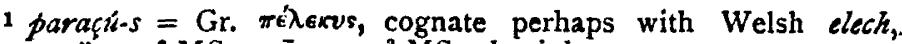
"saxum". "MS. oms̄ a. "3 MS. -thuaigh.
} 
Diancecht brought with him hither Every herb from precious ${ }^{1}$ I usmag To the well of the little healths, North-west of Moytura.

Also in BB. $406 \mathrm{a}$; H. 44 b; Lec. $488 \mathrm{a}$; and R. I12 b 2.

lusmag, "Herb-plain," now perhaps Lusmagh in King's County. The Achad Abla. "Field of the Apple-tree," here mentioned, has not, so far as I know, been identified. Northern Magh Tuiredh, the battlefield here mentioned, is now a townland in the barony of lirerrell, co. of sligo. For a romantic account of the battle, see Kevue Celtique, xii, 56-110. The healing-well is mentioned ibid., pp. $94,96$.

[72. Bens CoDAlL.]-Beand Codhail can a[s] rohainmnigeadh ? Ni ansa.

Codhol Coirrchicheach is e rob ${ }^{2}$ aide do Eirind diata Inis Erenn, $y$ is ann tairbreadh a dalta for in beind ud, $y$ nach tairbert dobeiread furri conogbhadh in talamh foaib, J mairberead Eiriu atumadar suas go tiagat a goth gæithe fu domhnaib a cluass man[i]abrad (sí) sin $\mathrm{y}$ rofhasfadh gomadh reil Eire uile as, $\mathrm{J}$ an la domela comarba Erenn no rí Temrach tuara Codhail nó ní d'enlaith nó d'fiaduch ${ }^{3}$ nó di iasc, forbraid a ghal y a slainte. Unde Beand Codhail.

Codhal Coirrchicheach go n-aibh topghais Erind abradchain, manbadh Eriu cæmh monur cia cia bad leiriu cæmhchodhul.

Benn Codail, whence was it named?

Not hard (to say). Codal, the Round-breasted, 'tis he that was fosterer to Eriu, from whom is the island of Erin, and on yon peak he used to feed (?) his fosterling, and with every .... he would put upon her the ground would rise up under them, and Eriu .. . . And the day that Erin's coarb (successor) or Tara's king shall partake of Codal's food, or aught of birds or venison or fish, his valour and his heaith increase. Whence Benn Codail, "Codal's Peak."

The rest of the prose, and the quatrain, are so corrupt and obscure in the Edinburgh codex and the other MSS. (BB. $406 \mathrm{a} ; \mathrm{H} .13 \mathrm{~b} ; \mathrm{L}, 516 \mathrm{a}$; and R. I 21 a I) that $I$ do not venture to translate them.

Benn Codail has not been identified.

Eriu is perhaps the queen of the Tuatha De Danann, mentioned in LL. 1o a and O'Mahony's Keating, pp. 82, If $1,198$.

[73. TlachtGA.]-Tlachtgha canas rohainmnigheadh? Ni ansa. Tlachtgha ingean Mogha ${ }^{4}$ Roith fordos-reibleangadar tri meic Simoin druadh ${ }^{5}$ dia luidh le hat $[\mathrm{h}]$ air da foglaim druidhechta $\mathrm{i}$

\begin{tabular}{|c|c|c|}
\hline $\begin{array}{l}1 \text { luaigne .1. logmar, O'Dav. } \\
f \text { inserted by the corrector. }\end{array}$ & $\begin{array}{l}2 \text { MS. romb. } \\
\text { MS. modha. }\end{array}$ & $\begin{array}{l}{ }^{3} \text { MS. dfiaguch, the } \\
\text { sS. druagh. }\end{array}$ \\
\hline
\end{tabular}


$\mathrm{n}$-airthiur in betha, fodeigh is $\mathrm{i}$ doroighni in Roth Ramach do Thriun $\mathrm{J}$ in lia i Forcarthu $\mathrm{J}$ in coir $[$ th] i Cnamhchaill. Ternai iaramh anair [y] in dedha sin le go torracht tealaigh Tlachtga. Fordos لlamnad annsin iarum go mberdais tri maccu .. . Doirb, dia ta Magh nDoirbi, J Cuma, dia ta Magh Cuma, J Múach, dia ta Magh Mu[a]ich. I cein dano beid in[na] anmand sin i cuimni fear nErenn ní thora digal n-echtrann docum nErenn. Ocus atbath dia hassaid, ${ }^{1} y$ is uirri dorindeadh in dun. Unde Tlachtga.

Tlachtga inghen Modha moir ros-lebhlan[g]adar meic Simoin. onn uair thanic dar muir mas is di ata 'Tlachtgha tæbghlas.

Tlachtga, whence was it named?

Not hard (to say). Tlachtga, daughter of Mogh Ruith, three sons of Simon Magus ravished her when she went with her father to learn wizardry in the eastern part of the world, because 'tis she that had made the Rowing Wheel for Trian (?) and the Stone in Forcarthu, and the Pillar-stone in Cnámchoill.

'Then she escaped from the east, bringing those two things with her till she reached the hill of Tlachtga. There, then, she lay in, and three sons were born, to wit, Doirb, from whom Mag nDoirbe (is named), Cumma, from whom is Mag Cumma, and Muach, from whom is Mag Muaich. So long as these names shall remain in the memory of the men of Erin, foreigners' vengeance shall not visit Ireland. And she died in childbed, and over her the fortress was built, whence Tlachtga.

Tlachtga, daughter of great Mogh,

Simon's sons ravished her.

From the hour that she came over the beautiful sea After her green-sided Tlachtga is (named).

Also in BB. $406 \mathrm{~b}$; H. $13 \mathrm{~b}$; Lec. $5 \times 6 \mathrm{~b}$; and R. 12r a. See also Silva Gadelica, ii, $5 \mathrm{rr}$.

Tlachtga is now the Hill of Ward, near Athboy in Meath, Four Masters, A.D. I 172, note $i$, and Book of Rights, p. ro, note $t$.

Forcharthu is near Rathcoole and Cndmchaill in Tipperary.

As to the wizard Mogh Ruith and the Rowing Wheel, which is to roll over Europe before Doomsday, see the Bodleian MS. Laud 6Io, fo. rog a 1 , and O'Curry's Lectures, pp. 272, 385, 401, 421, 423, 428. Of the Pillar-stone of Cnámchoill it is said in Laud 610, fo. rog a 2: Dall cach oen notn-aicfe, bodar cach oen nod-cluinfe, marb cach den risi mbenfa. "Blind (will be) every one who sball see it ; deaf every one who shall hear it ; and dead every one against whom it shall strike."

Mag Cumma (in Húi Neill, Four Masters, A.M. 3529), like Mag nDoirbe and Mag Muaich, is now unknown.

[74. Inber Cichmaini.]-INber Cichmaine can as rohainmnigheadh? Ni ansa.

1 MS. hassaidh. 
Cich-maine $e^{1}$ Adhnai mac Ailella $y$ Meadhbha, ar ba Maine Adnai in sechtmad mac do Ailill $\mathrm{y}$ do Meidhbh, ut supra diximus. IS e dano in Maine sin forruidbigh Feargna mac Finnchoime oc cosna $\mathrm{m}^{2}$ churaigh forsin tracht.

Nó Cichmuine mac Ailella find fuaradar araile iasgaire ic telach ${ }^{3}$ [al lin y a cocholl, coro marbsat isin inbiur (ucut). Unde Inber Cichmaini.]

Inber Cichmaini, whence was it named?

Not hard (to say). Cich-maine Adnoe, son of $\Lambda$ ilill and Medb, for Maine Adnoe was the seventh son of Ailill and Medh, as we said above. "Tis that Maine, then, that Fergna, son of Findchoem, slew (?) while contending for a boat on the strand.

Or Cich-maine, son of Ailill the Fair, certain fishermen found loosing their nets and their hoods. ${ }^{4}$ So they killed him in yon estuary, and hence Inber Cichmaini is named.

Also in BB. 405 a; H. 12 a; 1. 5 I5 a; and R. 120 a 2. From R. the words in. brackets have been taken.

Inber Cichmaini has not, so far as I know, been identified. O'Curry, Manners and Customs, iii, 162,188 , says it is on the east coast of Ulster. Etain was reared there, LU. 129 a 23 .

\section{(Egerton $178 \mathrm{r}$, fo. $75^{\mathrm{b}}$.)}

[75. Loch CÉ.]-Loch Cé, canus rohainmnighedh?

Ni ansa. Cé.r. drái Nuadhat Airgetlaim meic Echtaigh meic Eterlaim rotáet a cath Maige Turedh iarna guin isin cath co rainic Carn Coirrslébhi y co rainic in Magh Airni a fuil in loch, y docer Cáe ann sin, conid ica idhnacal ro mebaidh in loch. Unde Loch Cé.

Loch Cé, whence was it named?

Not hard (to say). Cé, the wizard of Nuada Silverhand, entered the battle of Magh Turedh. Having been wounded in the fight, he went to Corrshlébhe, and (then) he went to Magh Airni, where the lake is. And there Cé fell, and at his burial the lake burst forth. Whence is Loch Cé, "Cé's Lake."

Also in H. $66 \mathrm{~b}$; and Lec. 490 . Edited (with a translation) from the latter MS. by Hennessy, in the preface to his Annals of Loch Ce, pp. xxxvi-xxxix. The copy in $\mathrm{H} .66 \mathrm{~b}$ has never been published, and is as follows:

\section{Loch $\mathrm{Ce}$, canas roainmniged?}

$\mathrm{Ni}$ ansa. Antan rofechta cath Muighi Tuiredh eter Fomorchaib et Toatha De Danann, rogonadh dno ann drui Nuadat Arccetlaim maic Echtaig a fritguin an imair[i]g. Cé a ainm-side. La sodain doriecht roimi sierdes on muigh co torracht Carn

\footnotetext{
1 MS. ciachmhaine. 2 MS. finnchoinne ochosnam. ${ }^{3}$ telach .i. sgaoileadh, O'Clery. 'cocholl, borrowed from Lat. cucullus. P. O'Connell has cochall, a net, a fishing net.
} 
Corrslébe, co ndeissed as-suidiu iar scis ghona et uamain $\mathrm{j}$ imtechtai acht chena is suaill nar 'bo marb focetoir. asiu rofaccadh in carn forar' dheissed. Rosill uaid sairtuaidh cachndireach co facca in mag minscothach. Ba lainn lais rochtain an muighe atconnairc. Juid rome for an amthas fon indus sin co larmhedon in muighe, ait a mbui carrac cobsaidh comadbul, conadh [on] drai rohainmnigthe. $\mathrm{x}$. Carrac $\mathrm{Ce}$, conadh fon cairn roladh fo talmain iarna eibelt. Intan iarum roclas a fert is ann [ba] tomaidm an locha taris et $\operatorname{tar}[\mathrm{s}]$ in magh olchena. Unde Loch Ce.

Loch Cé, whence was it named?

Not hard (to say). When the battle of Magh Tuiredh was fought between the Fomorians and the Tuatha Dé Danann the wizard of Nuada Silverhand, son of Echtach, was wounded there in the brunt of the contest. Cé was his name. Thereat he fared forward south-west from the plain till he reached Carn Corrslebe, and sat down thereon (so) wearied with his wounding and fear and travel, that he almost died forthwith. From this was seen the cairn on which he sat. He looked due north-east, and he saw the smooth and flowerful plain. Fain was he to reach the plain that he saw. On he went on the .... in that wise to the very centre of the plain, where there was a rock, firm and huge, which was (afterwards) named from the wizard, to wit Carrac $C e$. And under the cairn he was interred after he had perished. Now when his tomb was dug there was an outburst of the lake over it, and over the rest of the plain. Whence is Loch Cé.

Loch Cl, now Lough Key, is a lake in the county of Roscommon, near the town of Boyle. Corrshliabh, the Curlew Mountains, also near Boyle.

As to the battle of Magh Tuiredh, see supra, No. $7 \mathrm{r}$, and Rev. Celtique, xii, 52 et seq.

As to Nuada and his silvern hand, ibid., 58, 66; LL. 9 a, 127 a; and the Four Masters, A.M. 3303.

[76. Mag nDumach.]-Magh nDumach, cidh dia ta?

Ni ansa. Cath doratadh imna tri druimnibh ada dech bái a nErinn. 1. Druim Crecht [fo. $\left.76^{\text {b }} 2\right]$ J Druim Betach a cuit Eremoin J Druim Fingin a cuit Ebir. Ba bec la hEber ændruim isin leth thes $\mathrm{y}$ a dó sa tir tuaidh, $\mathrm{J}$ atbert Erimon na bad athroinn uad dia cuit. Fertar cath etarru. Romebaid tra for Eber, condorcair ann Eber J Palap mac Eremon la Conmæl mac Cathbad, J rogníad dumad[a] ar in læchraidh annsin. Unde Magh nDumach, $]$ Tendais a ainm ar tus. Unde dicitur :

San cath for Tenndais na treabh

sin muigh a dorchair Eber,

a dorcradar ann malle

Goistin, ${ }^{1}$ Sétga ocus Suirge.

vol. IV. $\quad$ L L

1 MS. gorestin. 
A tochar ctir da magh

in $\mathrm{cl}$. f $r$ i bothar n-air

Eber mac Miled cobecht

is ed a leaiht anasb.

Unde Mag nDumach dicit[ur].

Magh nDumach, whence was it named ?

Not hard (to say). A battle was there delivered (between Eber and Eremon, two sons of Míl) concerning the three ridges which were best in Ireland, to wit, Druim Crecht [Cresach $-L$. Clasaigh $-F . M$.$\rceil and Druim Bethach in Eremon's portion, and$ Druim Fingin in Eber's portion. To Eber it seemed petty to have one ridge in the southern half and two in the northern country. And Eremon said that there would be no repartition by him of his share. (So) a battle is fought between them. Eber was routed, and therein fell Eber and Palap, son of Eremon, by Conmael, son of Cathbad, and mounds were built over the heroes there, whence Magh nDumach, "the mounded Plain," and Tendais had been its name originally. Whence is said:

In the battle on Tendais of the habitations,

In the plain where Eber fell,

There fell together

Goisten, Sétga, and Suirge..

On a causeway between two plains

..... to the east of a road,

Eber, son of Míl, certainly

This is his grave ....

Also in Lec. 524 b, but, so far as I am aware, nowhere else.

Mag $n$ Dumach is perhaps the place called by the Four Masters, A D. 858, Magh Duma, which O'Donovan says is now called Moy, adjoining Charlemont, on the 'Tyrone side of the Blackwater.

As to Eber and Eremion and their dispute, see the Four Masters, A.M. 350 .

Druim Clasaigh is a long hill in Hy-Many, between Lough Ree and the river Suck. Druim Beathaigh was the name of a ridge across the plain of Maenmagh. near the town of I,oughrea, in the county of Galway. Druim Finghin is a ridge extending from near Castle-Lyons in the co. of. Cork to the south side of the Bay of Dungarvan.

[77. CNucha.]-Cnucha, canas rohainmnighedh?

Ni ansa. Dia tangatar .u. meic Dela meic Loith cho Erinn, Gann y Genann J Rudraige J Sengann J Slaine, doratsat .u. righna leo.r. Fuat ben Slaine a quo (sic) nominatur Sliabh Fuait $\mathrm{J}$ inisin Fuata, Etar ben Gainn, isi atbath i nEtur, J is uaithi

1 These were, according to the Four Masters, "three distinguished chieftains of the people of Eremon." I cannot translate the following quatrain. 
ainmnigther Etar, Anust ben Sengainn, Lí ben Rudraigi, Cnuca ben Genainn, is i conapaid 'sin tilaig sin, $J$ is inti roadhnocht, conidh uaithi ainmnigther Cnucha.

Coig mna tucsatar aleth [leg. ille]

coig meic Dela can duilgi,

da mnai dibh Cnucha co mbladh

is Etur o trocht imglan.

Atbath Cnucha sunna tra

san cnuc ria n-abar Cnucha,

atbath Etur ben Gainn gluair

a $\mathrm{mBen}[\mathrm{n}]$ Etair re henuair.

De sin ata Etar án

is Cnucha cétach comlán,

is inis Fuata can ail

ocus Sliabh Fuait co morblaidh.

No Cnucha ingen Connaidh a hiathaibh Luimnigh, buime Cuinn Cétcathaig docoid ann do tham ina tigh fen [j] do hadhnaicedh la Connaidh (?) isin chnuc ugad .r. Crucha. Unde Cnucha dicitur].

Cnucha, whence was it named?

Not hard (to say). When the five sons of Dela, son of Loth, came to Erin, (to wit) Gann, Genann, Rudraige, Sengann, and Sláine, they brought five queens with them, to wit, Fuat, Sláine's wife (from whom is named Sliab Fuait and Inis Fuata), Etar, Gann's wife-'tis she that died on Etar, and from her it is named-Anust, wife of Sengann, Lí, wife of Rudraige, and Cnucha, wife of Genann. 'Tis she that died on that hill, and therein she was buried. Wherefore from her Cnucha is named.

Dela's five sons without trouble

Brought hither five wives:

Two of them were famous Cnucha

And Etar from the very clear strand.

Now Cnucha died here

On the hill called Cnucha,

And Etar, wife of pure Gann,

On Benn Etair at the same hour.

Thence is splendid Etar

And Cnucha, the very full,

And Inis Fuata without shame,

And Sliab Fuait with great renown.

Or Cnucha, daughter of Connad from the lands of Luimnech, fostermother of Conn of the Hundred Battles. She died there 
of the plague in her own house, [and she was buried by Conaing [leg. Connad ?] in yon hill, namely, Cnucha. Whence Cuucha is said.

The last paragraph (bui not the first, nor the verses) is contained in Lec. 525 a. I know of no other copy.

Cnucha is probably now Cisstlcknock, near Dublin. See O'Donovan's note $f$, Four . Masters, A.M. 3579.

As to the five sons of Dela, ibid., A.M. 3266, and LL. 127 a. As to their wives, BB. 283 a 5.8.

Benn Etuir, now Howth.

For Sliab Fuait a different etymology is given supra, No. 64. Inis Fuata not identified.

\section{CORRIGENDA AND ADDENDA.}

Folk-Lore, Vol. iii, pp. 470-516.

P. 470 , 1. 13, read Bregh[d]a.

" 273 , for Tea of Bregia read Bregian Tea.

P. $473,1$. 10, for the read its.

P. 475 , i. 4, for ónl read ón dub.

", l. 19, for came read was let.

". 1. 22, before river insert dark.

P. 476, 1. 15, for Hateful read A bad smoke; and in note 3 , for from . . mciden,

P. $48 \mathrm{I}, 1.7$, for in dail read ind ail.

"1. 23, for beauty read defence (?).

". 1. 26, for worded doom read shameful word.

P. 482, 1. 18, ufter an 1 u insert leg. a ndú.

P." l. 39. for to-day read (is) their place.

P. "483, 1. 21, for breast read belly.

P. 484,1 . 30, after Miandais insert leg. Anais.

P. $485,1.5$, after other insert (nuw Slievemish).

P. 486, 1. 14, after Samaisce insert [Ac Boibli dano robatar sain-LL.].

" l. 25, after Samaisce insert Now those belonged to Boible. ". 1. 37, for hardly ... Ulster read in Kerry; see the Four Masters, ed.
O'Donovan, i, p. 86 .

P. 487, 1. 2, mutcada should perhaps be corrected into múchtha, "of smothering". The contest was, apparently, to see which of the two combatants

P. 488,1 . 17, after toeb insert Side.

could drown the other. Compare Rev. Cell., v, 200 .

"I. 35, befure Nenta insert Sid. P. "489, 1. 13 , add Sid Nenta was a fairy mansion in Connaught, O'Curry, Lectures,

1. 22, for aib réad aibra.

P. "91, 1. 16, add Perhaps the latter is Magh Mossaidh, which O'Curry (Lectures, pp. 485,486 ) says is part of the barony of Eliogarty, not far from

P. 495, 11. 3, 4, read 'They, both hounds and men, drove the swine before them.

" I1. 28, 32, fur hounds read wolves.

"1. 42, for hounds read wolves.

P. 502, 1. 16, for Duiublind read Duiuhlind.

P. 505, i. II, read thabairt dochum.

" i. 19, for cre[d] ]umai forsin curuch read (with the corrector of LL.) forsin

P. 509 , 1. 20, for then read there.

P. 510,1 . 10, for doaing read do[d]aing.

P. 516, col, 2, insert Mag Luirg, 30. 


\section{INDEX OF PLACES.}

\author{
Achad Abla, 7r \\ Ard Fothaid, 60 \\ Ard Ladrann, 57 \\ Ard Macha, 6r \\ Belach dá Liacc, 55 \\ Benn Bairchi, 69 \\ Benn Boguine, 53 \\ Benn Codail, 72 \\ Benn Etair, 77 \\ Benn Foibni, 59 \\ Bri Léth, 6r \\ Carn Corrshlébe, 75 \\ Carrac Cé, 75 \\ Céis Corainn, 54 \\ Cera, 67 \\ Cnámchoill, 73 \\ Cnucha, 77 \\ Coire mbreccain, $5^{8}$ \\ Corrshlfab, 75 \\ Cruach Aigle, 67 \\ Cruachu. $5^{6}$ \\ Cualnge, 6r, 63
}

\author{
Cúil Cesra, 57 \\ Druim Bethaig, 76 \\ Druim Clasaig, 76 \\ Druim Fingin, 76 \\ Dún na mBarc, 57 \\ Dún Sobairchi, 69 \\ Emain, 6I, 64 \\ Fert Finntain, 57 \\ Findloch Cera, 67 \\ Forcarthu, 73 \\ Inber Cichmaini, 74 \\ Inis Fuata, 77 \\ Lia Lindgadain, 65 \\ Loch Cé, 75 \\ Loch Cuan, 69 \\ Loch da Caech, 69 \\ Loch n-Echach, 55 \\ Loch n-Eirne, $5^{6}$ \\ Loch Rib, 55 \\ Loch Ruide, 69 \\ Lusmag, $7 \mathrm{r}$ \\ Mag nAilbi, 66
}

\author{
Mag nAirne, 75 \\ Mag Coba, 62 \\ Mag Corainn, 54 \\ Mag Cúma, 73 \\ Mag nDairbtbenn, 55 \\ Mag nDoirbe, 73 \\ Mag nDumach, 76 \\ Mag Find, 55 \\ Mag Lamraide, 57 \\ Mag Muaich, 73 \\ Mag Mugna, 66 \\ Mag Tailten, 68 \\ Mag Tuired, 75 \\ Sliab Betha, 57 \\ Sliab Callainn, 63 \\ Sliab Fuait, 64, 77 \\ Tailtiu, 68 \\ Telach Bela, 70 \\ Tendais, 76 \\ Tlachtga, 73 \\ Tráig Tuirbi, 70 \\ Tul Tuinne, 57
}

Whitley Stokes. 